\title{
NEWS AND NOTES
}

Venereal diseases in the Colonies

The Colonial Office has made a new move to deal with venereal diseases. It announces that a subcommittee of the Colonial Advisory Medical Committee is to make recommendations to the Secretary of State concerning the problems of venereal diseases in the Colonies. This subcommittee will have as its chairman Mr. T. I. K. Lloyd, an assistant under-secretary of State in the Colonial Office; other members are Sir William Jameson, Sir Drummond Shiels, Dr. Mary Blacklock, Dr. Letitia Fairfield and Dr. Robert Sutherland in addition to the medical advisers to the Secretary of State.

Results of Regulation 33B

In Parliament recently Dr. Edith Summerskill asked Mr. Ernest Brown, Minister of Health; for information concerning the operation of Regulation 33B. The Minister replied : "Information now received from all but a very few authorities in England and Wales shows that thirtysix men and 475 women have been reported to medical officers of health as alleged sources of venereal infection, of whom one man and twenty-seven women have been the subject of more than one report, which is necessary before Regulation $33 \mathrm{~B}$ can operate. Of these twenty-eight persons two women have refused treatment, one expressly, and one by default, and havé been prosecuted and imprisoned. No civilian voluntarily undergoing treatment for venereal disease is subject to compulsion to complete it."

V.D. rehabilitation centre

The former home of Mr. and Mrs. Charles A. Lindbergh, Hopewell, United States of America, was accepted as a gift by the State more than a year ago. Plans to use it as a hospital and rehabilitation centre for women infected with venereal diseases have recently been approved by the State Department of Health.

\section{EDITORIAL NOTES}

The Editors beg to acknowledge with thanks the receipt of the following Journals, etc.

\author{
American Journal of the Medical Sciences \\ American Journal of Syphilis \\ British Journal of Dermatology \\ British Medical Journal \\ British Journal of Urology \\ - La Cronica médica \\ Indian Journal of Venereal Diseases \\ Indian Medical.Gazette \\ Irish Journal of Medical Science \\ The Journal of the Cape Town Post-Graduate Medical Association \\ Journal of Experimental Medicine \\ Medical Times, New York \\ Medicina Española \\ Memorias do Instituto Biologico Ezequiel Dias \\ New England Journal of Medicine \\ Prescriber \\ Revista de Sanidad y Assistencia Social \\ Revista del Instituto de Salubridad y enfermedades tropicales \\ Revista médica de Chile \\ South African Journal of Medical Sciences \\ Urologic and Cutaneous Review \\ Venereal Disease Information
}

